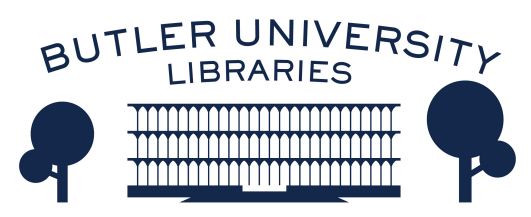

Journal of Hindu-Christian Studies

\title{
Book Review: "Was Hinduism Invented? : Britons, Indians, and Colonial Construction of Religion"
}

Andrew O. Fort

Follow this and additional works at: https://digitalcommons.butler.edu/jhcs

Part of the Religion Commons

\section{Recommended Citation}

Fort, Andrew O. (2007) "Book Review: "Was Hinduism Invented? : Britons, Indians, and Colonial Construction of Religion"," Journal of Hindu-Christian Studies: Vol. 20, Article 20.

Available at: https://doi.org/10.7825/2164-6279.1395

The Journal of Hindu-Christian Studies is a publication of the Society for Hindu-Christian Studies. The digital version is made available by Digital Commons @ Butler University. For questions about the Journal or the Society, please contact cbauman@butler.edu. For more information about Digital Commons @ Butler University, please contact digitalscholarship@butler.edu. 


\section{Was Hinduism Invented? :Britons, Indians, and Colonial Construction of Religion. Brian K. Pennington. New York: Oxford University Press, 2005. 260 pp.}

BRIAN Pennington makes an excellent case that the late eighteenth and early nineteenth century was a key moment in the development of modern "Hinduism" as a "world religion," both as concept and actuality. His book is also part of a welcome moderation from earlier scholarly arguments that "Hinduism" was largely a British invention to a more balanced view that it rose through a colonial encounter which fully recognizes Indian resistance and agency. Pennington states that he wants to avoid privileging either academic deconstruction of Hinduism or Hindu nationalist theologizing. He effectively demonstrates that many voices contested over a long period of time in ever changing sociopolitical conditions. He makes it his particular task to trace the development of British views, including those of Christian missionaries, and Hindu responses to the colonial Hindu-Christian encounter (particularly in Bengal), which makes this book relevant for review here.

From the introduction on, it is evident that Pennington is familiar with postmodern and postcolonial theory (particularity and plurality over essentializing and master narratives), yet he is not subsumed in it. He acknowledges the problematic nature of categories like "Hinduism" and "the West," without abandoning them. In particular, he wants to (appropriately, I believe) continue to utilize the category "religion" and a "history of religions" approach despite their highly contested nature by various theorists. As a student of Wilhelm Halbfass, I was particularly glad to see Pennington's balanced appreciation of that late scholar, and agree that while today we might find a bit Halbfass too focused on elite Hindu thought and not enough on popular practice or issues of power, he has not been superseded in his synoptic and richly humanistic vision.

Chapter two considers upper class British missionaries', strategies for Christian training and conversion. Pennington points out the interesting parallels between upper class perceptions of British factory laborers and "heathen pagans." In both cases, the elite understood their concern to be for civilizing and assisting the poor and benighted. He focuses here on the self-understood moral crusaders Hannah More, William Wilberforce and Charles Grant, and the success of the evangelical Church Missionary Society and writings in (and income generated from) its Missionary Papers.

The next chapter looks at the British Protestant evangelicals understanding (and in fact partial creation) of Hinduism after first hand experience in India, and their hostility to Hindu ritual and horror at "idol worship." $\mathrm{He}$ effectively points out their inability to understand a murti as God's image rather than a mere idol, and the linkage of Hindu and Catholic "idolatry" by such figures as Charles Buchanan. Perhaps most interesting is his description of William Ward as a proto-ethnographer of Hindu life, which included a portrayal containing typically strong British views against caste, sati, and linga worship. This chapter illuminates some of the least attractive aspects of zealous British moral imperialism.

Chapter four focuses on the journal of the British Asiatick Society called Asiatick Researches, which well represented nineteenth century British Orientalist perspectives, and how these views moved gradually from Indophilia to Indophobia over this period. In the late eighteenth century, beginning with William Jones, we find a focus on the exotic and "enchanting" nature of Indian plants and animals. There was also some investigation of non-Hindu religious groups and the adivasis, who are seen as noble but childlike savages. Over time, journal authors developed the idea of an India with a glorious past which had devolved to a corrupted present, and lamenting ongoing Hindu "mythological" thinking with its fables and poetry over against modern British "rationalism," with its concern for reality-based history and science. Pennington here briefly discusses H. T. Colebrooke's groundbreaking 
textual studies and H. H. Wilson's consideration of "living Hinduism."

Pennington then turns to the elite Bengali Hindu response in the biweekly newspaper Samacar Candrika beginning in the 1830s. The paper was anti-reformist and against modernists like Ram Mohan Roy and the rationalist monotheism of the Brahmo Samaj. It opposed the proposed ban on sati, and defended traditional Hindu ritual and popular religion (like Kalipuja), and made some appreciative remarks about the British (the justice system and infrastructure building), though it remained strongly anti-missionary. Samacar Candrika was thus a good example of the complexity of British-Indian interaction and power relations as "Hinduism" is constructed.

Finally, chapter six offers an expanded argument for retaining categories like "Hinduism" and "religion," despite their relatively recent and still contested construction. I found this the most interesting and valuable part of the book, with his call for a balanced recognition of their utility while simultaneously resisting any essentialism clear and persuasive. He rejects Timothy Fitzgerald's view that the category "religion" is fundamentally empty and theological, and offers a good critique of Russell McCutcheon's focus on religion as social construct and seeming insufficient concern with the self-understanding of religious communities. In closing, Pennington acknowledges that the past is not merely past as far as Christian-Hindu tensions go. He refers to the 1999 murder of the medical missionary Graham Staines by Hindu nationalists and the Southern Baptist Convention's pamphlet lamenting the millions "lost in the hopeless darkness of Hinduism." He decries the excesses of Hindutva and points out that Christianity has in fact been indigenous to India for many centuries. He ends with a laudable call for ongoing scholarly inquiry which acknowledges past flaws and includes both engagement with and more accurate understanding of Hindu groups yet also continues to offer deeper analysis not constrained by insiders' self-understandings. I share his concern that some of the more deconstructive scholars in academe can contribute to the frustration and indignation felt by living religious communities, who then can lash out unproductively in word and act. Thus, this book has real value in saying something both about the past and the present.

Andrew O. Fort

Texas Christian University

\section{The Asian Jesus. Michael Amaladoss, S.J., Maryknoll, NY: Orbis Books, 2006, $180+$ xi pages.}

MICHAEL Amaladoss stands out as one of the most prolific and influential Catholic theologians in contemporary India. Currently director of the Institute for Dialogue with Cultures and Religions in Chennai, Amaladoss has held teaching posts in India and Europe, served such international bodies as the Pontifical Council for Interreligious Dialogue of the Roman Catholic Church and the Commission on World Mission and Evangelism of the World Council of Churches, and published very widely over the course of some thirty-five years. His work - and reviews of his work-have appeared regularly in this journal, most recently in 2002 and 2004. In The Asian Jesus, Amaladoss speaks from this breadth of experience with a special self-consciousness of his identity as an "Indian" and, more broadly, as an "Asian Christian." "As an Indian and an Asian Christian," he writes, "I feel that Asian cultures and religions are not foreign to me. They are my heritage" (6). And so he writes this slim volume, not primarily for scholars, but for "the ordinary believing Asian Christian" who wants to reclaim that heritage and allow it more deeply to inform her Christian faith (8).

Given the intended audience, it comes as no surprise that The Asian Jesus does not engage in detailed enquiry or comparison on the topic of Christology. Instead, Amaladoss offers brief, 